\section{ISSN 2587-4713}

\section{DOI: $10.36962 / \mathrm{EC}$}

\section{DCONODICS}

VOLIMIE IOA.

ISSUE 3-5. 2021

oman 104, 3-5. 2021

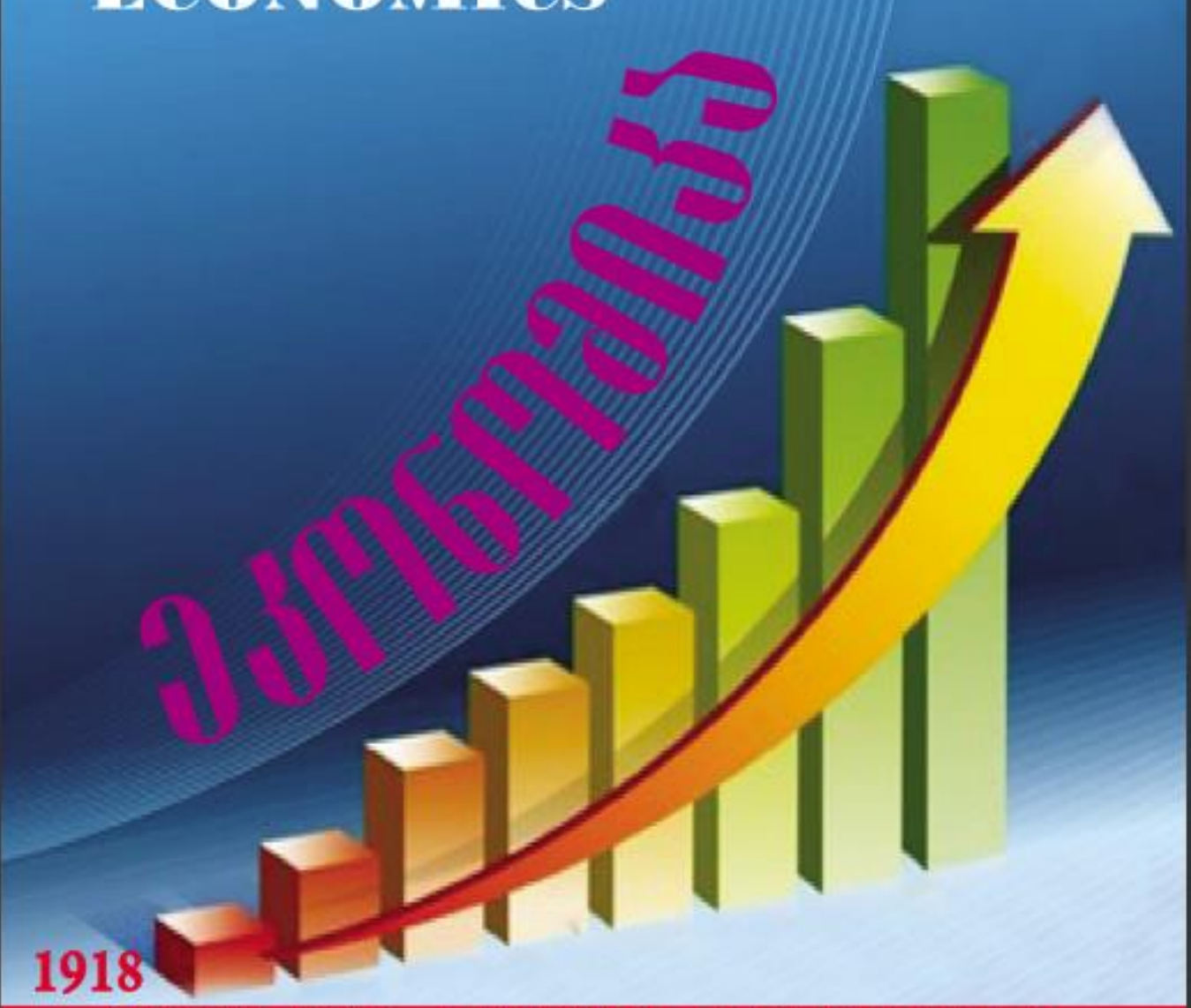

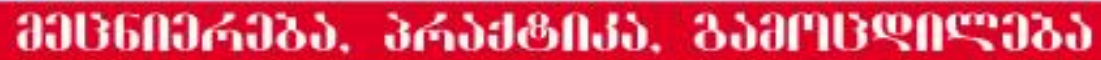
SCIENCE, PRACTICE, EXPEIRIENCE 
ISSN 2587-4713 DOI:10.36962/EC

\section{Јз๗бюанзง ECONOMICS}

в円

VOLUME 104, ISSUE 3-5 2021

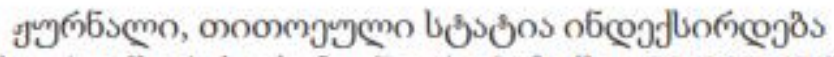

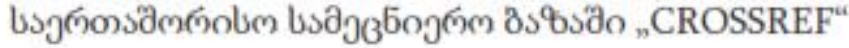

JOURNAL INDEXING

CROSSREF

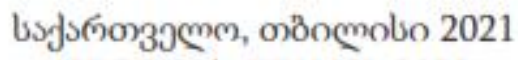

GEORGIA, TBILISI, 2021 


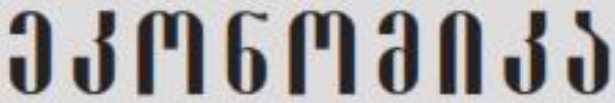

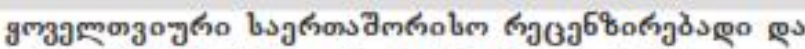

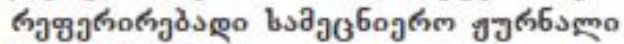

„ЭКОНОМИКА" - Ежемесячный международный рецензируемый и реферируемый научный журнал

"ECONOMICS " - Monthly International reviewed and refereed scientific journal

Sman 104, 3-5. 2021

VOLUME 104, ISSUE 3-5. 2021 DOI: $10.36962 / \mathrm{EC}$

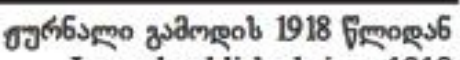
Journal published since 1918

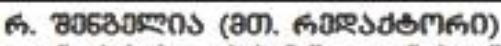

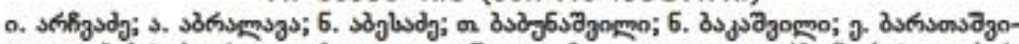

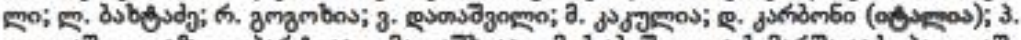

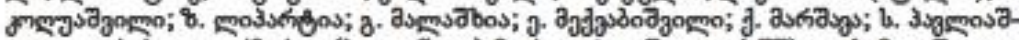

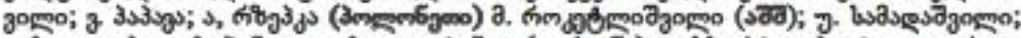

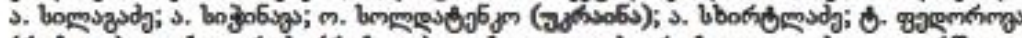
(

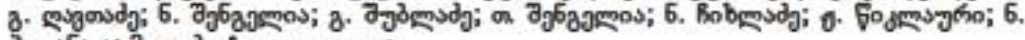

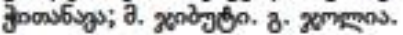

ШЕНГЕ ТИЯ Р. (ГЛ. РЕДАКТОР)

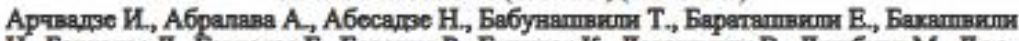

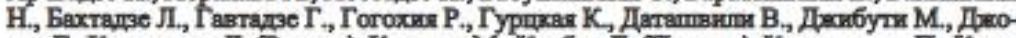

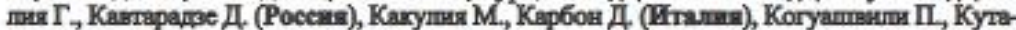

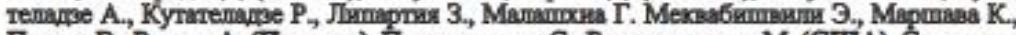

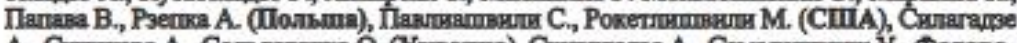

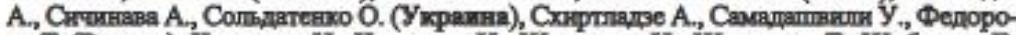

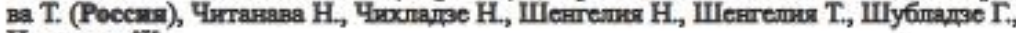
Циклаурн Ж.

\section{REVAZ SHENGELIA (EDITOR IN CHIEF)}

I ARCHVADZE; A. ABRALAVA; N. ABESADZE; T. BABUNASHVILI E. BARATASHVILI; N. BAKASHVILI; L. BAKKTTADZE; N. CHIKHLADZE; O. GHAVTADZE; R. GOOOKHLA; V. DATASHVIII M. KAKULLA; D. KARBON (ITALY); P. KOGHUASHVILI; Z. LIPARTIA; G. MALASHKKIIA; B. MEXVABISHVIL; K. MARSHAVA; S. PAVLIASHVILI; V.PAPAVA; A. RZEPKA (POLAND); M. ROKETLISHVILI (USA); U. SAMADASHVIL; N. SHENGPLA; A. SIL.AGADZE; A. SICHINAVA; 0 . SOLDATENKO (UKRRAINE); A. SKKHIRTLADZE; T. FEDOROVA (RUSSIA); D. QAVTARADZE (RUSSIA); A. QUTATELADZE; R. QUTATELADZE; K. GHURTSKAIA; O. SHUBLADZE; T. SHENGELIA; ZH. TSIKI.AURI;N. CHITANAVA; M. JIBUTI; Q. JOLLA.

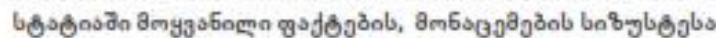

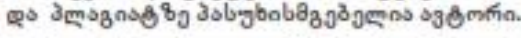

The Author is responsible for plagiarism and for the accuracy of the facts, data given in the article.

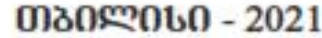




\section{CONTENTS}

\section{ECONOMIC REFORMS: ANALYSIS, PROBLEMS AND PERSPECTIVES}

Nato Gegenava, Tamar Abuashvili - The Main Reasons and Goals of the Pension Reform in Georgia

\section{MODERN PROBLEMS OF ECONOMICS}

Revaz Shengelia, Zhuzhuna Tsiklauri-Shengelia, Natia Shengelia Education - As One Main Form of Human Capital_____________ 17 Khatuna Shalamberidze, Nana Benidze - The Peculiarities

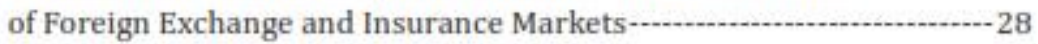

FINANCES, BANKS AND EXCHANGE MARKETS

Bagrat Devadze, Giorgi Devadze - Financial and Economic Indicators of Shipping Companies in 2010-2019 Years $-41$

Tengiz Lachkepiani, Maya Kiladze , Mtvarisa Tananashvili, Maia Lomishvili - The Essence of "Green Bonds" and Issues of Effective Management in Georgia

\section{REGIONAL ECONOMY}

Gocha Tsopurashvili - The Role and Opportunities of the Regional Economy in the Agrarian Sector in Ensuring the Production of Competitive Products $-60$ Paata Koguashvili, Gocha Tsopurashvili - Regional Aspects of Land Management Policy and Self-Governance Possibilities ---.-----79 Mariam Kenchoshvili - The Solution Ways of the Agricultural Problems in Samtskhe-Javakheti Region $-95$ 
Lado Arabidze - Modern Trends in Development of Winemaking --- 105

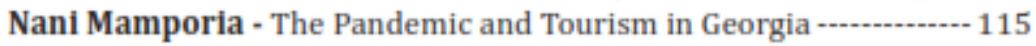

Nino Omanadze - The Impact of the Pandemic on Staff

Work Schedules and Incentives on the Example of "Taxi Prius" ------- 125

Paata Koguashvili, Lado Arabidze - Optimization

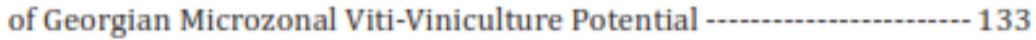

\section{BUSINESS, MANAGEMENT, MARKETING}

Salome Imnaishvili - The Importance of Business -

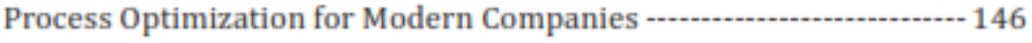

Rami Aljabali - Emotional Intelligence and

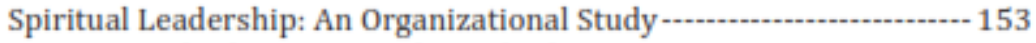

Nino Ositashvili, Nana Nadareishvili - The Role

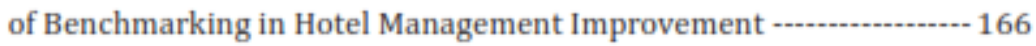

Bagrat Devadze - The Role of Liner Shipping Services

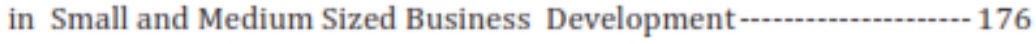

Manana Samadashvili, Ekaterine Gobejishvili -

Human Resources - the Main Driving Force of The Organization ---- 184

\section{WORLD ECONOMY}

GRIGOL GLUNCHADZE - DEVELOPMENT OF GEORGIA'S

TRADE RELATIONS WITH UKRAINE

Publication Requirements 175 


\title{
Resumes
}

JOURNAL ECONOMICS, VOLUME 104, ISSUE 3-5, 2021

\section{The Main Reasons and Goals of the Pension Reform in Georgia}

\author{
Nato Gegenava, \\ GTU Associate Professor \\ nato.gegenava@mail.ru'; \\ Tamar Abuashvili \\ GTU Associate Professor \\ t.abuashvili@gtu.ge
}

\begin{abstract}
Resume
The concept of pension reform is a government's plan to improve the pension system and reflects the long-term risks and takes into account the socio-economic reality in the country. The aim of the reform is to protect better existing retirees from poverty through indexation, which is guaranteed to maintain the retiree's purchasing power level; Providing the next generation of retirees with a higher pension income, which will be directly proportional to the income received during the employment period and the profit of the pension fund. The private pension system will allow employed citizens to plan better their retirement age and not depend only on state funding and be able to mobilize a certain amount before reaching retirement age.

The need for reform stems from negative factors such as: an increase in the number of people of retirement age, a decrease in the birth rate, a decrease in the working age population, migration processes, etc. Analysis of the existing system show that it is impossible to maintain or improve the existing replacement ratio only in the medium and long term at the expense of state funding. The private accumulation model will be an additional component of the pension system, which will contribute to a significant increase in the replacement rate.
\end{abstract}

The existence of a private accumulation system will make it possible to define better the fundamental principle of social pension, which implies protection of the population of retirement age from poverty. To achieve this goal, it is important that the social pension 
does not fall below the subsistence level and also that the pension should be increased at least in parallel with inflation or in the event of economic growth above inflation.

Keywords: Pension system, Reform, Pension fund, Government, Population.

\section{Education - As One Main Form of Human Capital}

Revaz Shengelia ${ }^{1}$, $\mathrm{PhD}$, GTU, Professor,

Zhuzhuna Tsiklauri-Shengelia ${ }^{2}$, $\mathrm{PhD}$, GTU, Professor, Natia Shengelia ${ }^{3}$, PhD, GTU Associate Professor, Invited Lecturer at Lublin University of Technology economica_1918@yahoo.com¹h_jujuna@yahoo.com² natia.shengelia@oxfordbrookes.net ${ }^{3}$

\section{Resume}

Education is the driving force for economic development and raising living standards. As an active factor of production - a sophisticated person determines the socioeconomic development of a country. Truly, there are many factors hindering the rapid development, of which solution in a relatively short time is impossible (f.ex. returning of occupied territory); However there exist other kind of problems (development of infrastructure in a short time, cost saving on maintaining the state bureaucracy and leaving more money for the economy; having reliable money in circulation; an effective social assistance system, etc.), which can be eliminated in a short time. Among such important problems, the most important is to raise the level of human education, so, the qualitative level of human capital development.

In order to make the country attractive in the conditions of rapid competition, it is necessary to create an innovative, creative atmosphere for the introduction of the updated 
education system, for the improvement of human capital. That should ensure the continuous update of the knowledge obtained at the higher Education institutions in parallel with the scientific and technical progress improved level. All this requires a lot of private initiatives, less regulation by the state and in the right direction of finances, reasonable and targeted spending.

In Summary, the goal of the ongoing education reform is to make education not just as as a business but to make it more as a public good. Since education is the most significant sphere for accumulation of human capital and dissemination of knowledge in modern digital economy, it is necessary to increase the role of the state in improving this field.

Keywords: Human Capital, Investment, Education, Competition.

\title{
3. The Peculiarities of Foreign Exchange and Insurance Markets
}

\author{
Khatuna Shalamberidze ${ }^{1}$ - Doctor of Economics, Akaki \\ Tsereteli State University; Kutaisi University - \\ Associate Professor; \\ xatuna-shalamberidze@mail.ru1 \\ Nana Benidze ${ }^{2}$ - Doctor of Economics, Akaki Tsereteli \\ State University - Associate Professor; \\ benidzenana@mail.ru²
}

\section{RESUME}

Foreign exchange risk is one of the most important components of the financial market. Like any other financial risk, it can be managed or avoided. Financial risk management requires the relevant knowledge and resources and only specialized financial institutions are engaged in doing so. Thee commercial banks do not accept foreign exchange risks, their assets and liabilities are denominated in the same currency. Therefore, it is recommended for households and businesses to avoid the currency risk.

People's behavior is different during the sharp fluctuations of exchange rates. There is no ideal tactic for behavior. However, we would like to share some basic tips to help you reduce your expected financial risks; At the same time, the undesirable attitude characteristic of the period of strong fluctuations in the course will become clearer and 
more preventive. We hope that the information presented in such circumstances will help you to make the right decision.

Keywords: Foreign exchange and insurance market efficiency; Exchange rate risk insurance; Involvement of financial instruments.

\section{Financial and Economic Indicators of Shipping Companies in 2010-2019 Years}

Bagrat Devadze,

Academic Doctor of Economics, Associate Professor of

Batumi Sea Maritime Academy bagratdevadze267@gmail.com

Giorgi Devadze, Senior Specialist at Financial Service Center of Mylan Corporation

\section{RESUME}

Financial and Economic analysis of shipping companies conducted based on main maritime industry segments - Crude Oil, Products, Liquefied Natural Gas (LNG), Dry bulk commodities and Container cargo. Each of them is represented as one or several companies, which are the leaders in these business sectors.

The revenues of shipping companies specialized in crude oil and product transportation have been increased significantly in 2010-2019 years, which was a result of increasing ship quantities and tonnage as well as income from time-charter. Stability can be seen in the revenues of liquefied natural gas shipping companies. The growth rate of container shipping company income was comparatively low. 
Moreover, the share of voyage costs have been increased in bulk commodities transportation in 2010-2019 (From 8\% to 25\%), decreased operating expenses, amortization of assets, charter and general costs. In the cost structure of liner shipping companies' transportation and terminal expenses have been increased (From 10\% to 26\%), while the share of fuel, charter and logistics costs have been decreased.

The high and stable profitability incurred in liquified natural gas transportation field as well as in oil shipping transporation with modern, new and large size oil tankers. The dry bulk and liner shipping companies were characterized with sharp unsteadiness and comperatively low profitability.

The crude oil and product shipping companies had positive financial results in 20142016 and 2019 years, in other years they reported loss. The liquified natural gas transportation companies had a stable profit. Within the same period, dry bulk shipping companies were characterized with the lower or even unprofitability. Container shipping companies had unsteady financial results, in particular their net profit was peaking in 2010, 2014 and 2018 years and ended up with loss in 2011 and 2016 years.

Keywords: The revenues of shipping companies, voyage costs, operational costs, charter costs, bunker costs, terminal costs, intermodal costs, port costs.

\section{The Essence of "Green Bonds" and Issues of Effective Management in Georgia}

Tengiz Lachkepiani ${ }^{1}$ - Academic Doctor of Economics , Georgian Technical University, t.lachkepiani@gtu.ge ${ }^{1}$ Maya Kiladze - Associate Professor, Academic Doctor of Engineering, Georgian Technical University, maya_kiladze@yahoo.com²

Mtvarisa Tananashvili - Associate Professor, Academic 
Doctor of Engineering, Georgian Technical

University, mtvarisa.tananashvili@mail.ru ${ }^{3}$

Maia Lomishvili - Assistant Professor, Georgian Technical University lomishvilimaia10@gtu.ge ${ }^{4}$

\section{Resume}

Green bonds can be considered as a model of economic development, that reduces environmental risks and ecological problems, promotes sustainable development, reduces the negative impact on the environment. In addition, it can be considered as a mechanism for the sustainable development and poverty eradication, and its result will also improve the human well-being and social equality.

Like any new form of financing, including "green bonds", it is still in its infancy and can be evaluated after some time. We think this financing tool will be useful for financing environmental projects. In addition, the establishment of the new Green Bank (or fund) will facilitate the direct investment or risk mitigation tools, or both, for the climate-related projects. LEDS and NEEAP have independently submitted options for setting up a public organization with a special mandate about green funding. Investors, commercial banks and corporations operating in Georgia may benefit from such a national funding organization for climate change measures to protect their investments from risks.

One of the priority directions of ecological relations for Georgia is the creation of normative acts, which enable the unification and harmonization of ecological legislation, including in the field of "green economy". The development of "ecological technologies" is also of great importance for the development of the "green economy". The "green economy" strategy should become a model of sustainable development in the long run.

In Summary, Green bonds may have been a good response by governments to restore the pandemic-reduced economic activity. With the reduced liquidity, this could be a good 
opportunity to access capital and increase investor confidence in the private sector and to attract more investments.

Keywords: Green bond, Financial market, Issuer, Finance, Green Bank.

\title{
6. The Role and Opportunities of the Regional Economy in the Agrarian Sector In Ensuring the Production of Competitive Products
}

\author{
Gocha Tsopurashvili
}

GTU PhD student

Gocha.tsopurasvili@gmail.com

\section{RESUME}

The paper discusses the importance of using the opportunities of the regional economy in the production of competitive agricultural products at the modern stage. The 8year cycle of declared priority and state protectionism has not substantially changed the situation, the field still needs to bereformed, most of the systemic-structural and organizational-technical issues are unresolved. The importance of the synergistic effect of centrifugal policies is completely ignored. Georgia's commitments under the Deep and Comprehensive Agreement with the European Union in terms of strengthening, decentralization and deconcentration of self-government, are not actually fulfilled; Therefore, in the current situation, the opportunities of the regional economy are untapped in the country. Accordingly, nowadays the opportunities of the regional economy are unused in the country, initiatives and proposals from the places are not considered at all. The principle of action adopted in the EU countries, which actively use the specific model in governance, is completely ignored. Moreover, all types of stimulus and protectionist policies are implemented only from the center and lack of the full-fledged on-site resource research, understanding the information-analytical reality, the visions of identifying risks and benefits, as well as the initial competitiveness. Solving the issues of territorial arrangement of Georgia, the active use of the opportunities of the regional economy and proper spatial development of the territories give us additional opportunities to solve the existing problems in the field and to ensure the activation of mechanisms for creating the competitive products. The agenda raises the need to address a number of fundamental problems that can be broken down into stages and implemented in the form of targeted 
action-program modeling. In order to make full use of the regional factor, it is necessary to be directly involved in policy management issues and to offer a microzonal adjusted incentive system, synergistic effect of centrifugal and centrifugal policies, generalization of all local specific problems, situational and contextual analysis, resource research. The role of an active land management policy issues, the establishment of the principles of competitive culture zones and the definition of sectoral-territorial specifics are an incomplete list of topics.

Moreover, in order to achieve competitiveness, it is important to highlight the starting advantage, which in this context must beexercised under multilateral responsibility, where both levels of the state hierarchical system will have their own rights and responsibilities. And the structural unit (cooperative, cluster) is fully responsible for ensuring the project-defined outcome. By implementing the regional economic principles, it is possible to consider the economic-commercial, on the one hand, within the framework of the targeted program, and on the other hand, the socio-demographic aspects that underlie the state policy on the development of the sector and the region. In the current situation, the importance of the convergent nature of development and inclusive involvement, which should be the result of a reasonable policy of the state, and it has no alternative in the current situation.

Keywords: regional economy, competitive products, involvement of self-governing bodies, decentralization, socio-economic situation, System-structural reform, analytical studies, targeted programs.

\section{Regional Aspects of Land Management Policy and Self-governance Opportunities}

Paata Koguashvili ${ }^{1}$

GTU Professor.

Paata_koguashvili@hotmail.com ${ }^{1}$

Gocha Tsopurashvili ${ }^{2}$

GTU PhD student 
gocha.tsopurashvili@gmail.com²

\section{Resume}

One of the most important foundations of sustainable economic development is a prudent land management policy, which in turn is complex and addresses the nature of socio-demographic problems. The Covid-19 pandemic has brought to the forefront the importance of self-sufficient agricultural development and food security has become one of the modern challenges, with land as the spatial basis of the economy. The new legislative norms and rules enacted in the country from 2020 require active actions by both the central government and local self-governments. UN studies and recommendations emphasize the importance of complex, multisectoral cooperation and separate the responsibilities of all three levels (center, region, self-government), where elements of duplication must be eliminated and actions taken in full coordination. The axis of the main strategic vision is the central government, its cooperation and activation of the regional factor in terms of assigning coordinating, concentrating functions is extremely interesting, which is unconditionally expressed in terms of efficiency and flexibility of the case. Action in time and space is much more effective than the process of self-regulation. In determining the main directions of the land policy, it is important to outline hierarchically and functionally correctly the responsibilities and obligations of the law enforcers.

Morover, the paper outlines the principles of cooperation and coordination, but at the same time emphasizes the importance of fulfilling the exclusive, statutory functions of self-government in terms of targeted and effective use of agricultural land in the country. Determining the market value of land, introducing differentiated taxes and creating a qualitative classification in modern conditions is one of the important challenges. To address these issues, an action software model is presented on the example of Bolnisi Municipality, based on sustainable development, economic Principles of optimization and rationalism, therefore accurately and objectively reflects the real situation. It is noteworthy that the mechanisms for determining the market value of land are created by a system and not an expert opinion brought to the air, the incorrect examples of which have accumulated quite a lot in the country. The approaches and action model proposed in the paper require the introduction of scientific thought and modern innovative systems in terms of quality assessment on the one hand, and on the other hand in terms of objective differentiated tax, because the precise definition of the real picture is the basis for a well-organized systemicstructural reform, which the field unconditionally needs even today.

Keywords: Land management policy, market price, local government, agriculture, land balance, soil, optimization.

\section{The Solution Ways of the Agricultural Problems in Samtskhe-Javakheti Region}




\section{Kenchoshvili Mariam}

Doctoral Student of

Samtskhe-Javakheti State University

\section{Resume}

In Georgia agriculture faces many challenges though there are few beneficial movements in this sector. As the article mainly describes the challenges of potato production development, the statistical data analysis will be useful. In 2008-2019 local potato supply rate was increased from $86 \%$ up to $93 \%$ in the country, especially in the condition when the potato land plots reduced from 24 thousand to 16.4 thousand ha, while the quantity of the produced potato has been increased unequally. Rural farms, regardless they are domestic or commercial are still flexible on the market against the prices of other agricultural product, this was the reason why the total potato land plots used to increase or reduce. In many cases the reason for reduction of the plots is the problems with harvest sales and low prices compared to primary cost of the product due to which the cultivated land plots were reduced. In addition, 99\% produce potato.

The majority of Samtskhe-Javakheti residents was and is engaged before and now in the agriculture actively. The region population is actively involved in both crop production and livestock breeding. The speed of production volume changing in the agriculture gives us possibility to base regional development concept on agricultural development in combination with the processing industry. For the recent years the size of the state funding of the sector is permanently increasing, though there are many indicators showing that it is early to talk about quality improvement of the field.

Additionally, the article discusses the steps made towards development of agriculture and there are stipulations about the reasons of their ineffectiveness. The solution ways and directions are also suggested for overcoming the causes on the example of Samtskhe-Javakheti region. By considering the fact that potato production is the major direction of the crop production in Samtskhe-Javakheti, the discussion mainly focuses on existing situation in potato growing of the region, analyzing the situation, threats and opportunities, strengths and weaknesses. 
In Summary, we have developed the model for the region in order to have a precedent for overcoming the challenges in the potato production, which will show the rural household and enterprises how it is possible to reflect supporting policy of the state on the financial results of the activities. The model does not require great financial expenses, though it can be an important stimulus for other domestic farms and the example for the regional cooperatives developed on the model, supporting to development agriculture and entire region together processing industry.

Keywords: Agriculture, potato production.

\section{Modern Trends in Development of Winemaking}

Lado Arabidze

Ladomet14@gmail.com

Doctorate at Georgian Technical University

\section{Resume}

Each year wine production is increasing in the world. New consumers emerge from around the world. As the wine business increases the new trends come on the consumer market and winemakers are trying to keep up. By the information from Statista - biggest business data platform in 2019 sales of the wine in dollars was 378277 million USD.

For the wine business 2020 was big challenge. As the world was covered with pandemic disease COVID-19. During the first part of the year the sales of almost every product got decreased, same happened to the wine market. So, the wine producers had to create new trends of selling the wines. This way the wine business started to adapt with the world pandemic situation. In the end of the 2020 you can already meet new trends in all the parts of the winemaking like: production, marketing, sales, logistics etc.

As 2020 was a big challenge in winemaking, the new trends have been created. In the article we discuss what has become popular in 2020 and what had changed in the trends of wine consumer market. We discuss the trends like online wine markets and sommelier. Also, Article will include the types of wines that became trends in 2020. In the article we have outlined all the opportunities, which helped wine sector and the people who work in winemaking to adapt the changes in world. We have analyzed the most innovations that has 
emerged with modern technology and methodology of production. Also, we have discussed the influence of the new trends on social and financial profit.

In the end we summarized all the trends and possibilities to implement them in Georgian vitiviniculture, how each opportunity will affect Georgian economy. The purpose of the development is to increase the quality and also to keep up with the modern demand on both local and international markets.

Keywords: Modern Trends, wine trends, international wine economics, Covid-19 situation, international experience in wine industry.

\title{
10. The Pandemic and Tourism in Georgia
}

\author{
Nani Mamporia \\ Associate Professor of \\ Georgian Technical University \\ mamporianani11@gtu.ge
}

\begin{abstract}
Resume
The article highlights the overview of the Georgian tourism sector; The economic downturn caused by the pandemic; Rising unemployment; Anti-crisis plan for tourism;

The spread of COVID-19 is a significant challenge not only in the field of health, it has covered all social and economic aspects of our lives. The virus, which was originally detected in the Chinese city of Wuhan in December 2019, has spread rapidly around the world. On January 30, 2020, the World Health Organization declared the 2019-2020 coronavirus epidemic an international public health threat, and on March 11, a pandemic. The pandemic has caused significant damage to almost all sectors of the economy, most severely the tourism sector, including all the areas that make up this industry.

Tourism is one of the main sources of growth in economic activity and accounts for $10 \%$ of world GDP. It is considered a vulnerable economic activity because it is relatively more sensitive to external shocks. Tourism is a very valuable and important source of employment for the population, inflow of foreign currency into the country, regional and
\end{abstract}


infrastructural development, economic and social progress, creation of various products or services in the country. Therefore, the recent developments have had a direct impact on countries' revenues, which has ultimately led, directly or indirectly, to large losses. According to the spread of the virus, the worst situation is in the countries that have been the most popular destinations for tourists in recent years (Italy, France, Spain, USA). It can be said that the large number of tourists turned out to be the main reason for the rapid spread of COVID-19 in these countries.

Keywords: International tourism, the Pandemic, Economic crisis, Domestic tourism.

\section{The Impact of the Pandemic on Staff Work Schedules and Incentives on the Example of "Taxi Prius"}

Nino Omanadze

Doctor of Business Administration

Georgian Technical University

ninoomanadze22@gmail.com

\section{Resume}

The article discusses the staff work schedule caused by the current pandemic and the impact of the incentive process on the example of Taxi Prius. It mentions what motivation is and what it does to increase the effectiveness of staff activities in general and in the organization in particular. The article outlines the pros and cons of the changed work schedule caused by the pandemic at Taxi Prius.

It emphasizes the importance of constant communication with staff by the human resource managers during the modern challenge, listening to their opinions, appreciating the performance of employees, empathizing with them and ensuring employee involvement in the work process.

Moreover, the paper presents the results of a survey of Taxi Prius employees, which showed that the preferred work schedule or work model for staff would be if managers would allow them to work remotely partially even after a pandemic or create a mixed work schedule model. This will increase the incentive for staff to do their job effectively.

The article states that the coronavirus pandemic shattered the stereotype that a person could not work in an environment other than the office. There was also the possibility of having a flexible / mixed work schedule based on the interests of the organization and the specifics of the work.

Keywords: the Pandemic, staff, work schedule, incentives. 


\section{Optimization of Georgian Microzonal Viti-Viniculture Potential}

Paata Koguashvili ${ }^{1}$, Professor, Georgian Technical University paata_koguashvili@hotmail.com 1

Lado Arabidze ${ }^{2}$

Doctorate at Georgian Technical University Ladomet14@gmail.com²

\section{Resume}

The article discusses Georgian microzonal vini-viticulture potential. We have described Georgian wine denomination of origin production and trends. Also, we have analyzed the current situation and perspectives of micro zone agriculture. The appellation wines are different from table wines and has the international economic value. We have provided evidence with the example of local and international experience, that the development of the wine appellations is one of the best ways to develop wine economics. We have made conclusion about the advantages of this kind of wines. In the end we provided the recommendations about studying, developing and forming wine microzones.

Both based on the experience of Georgian and international countries we have analyzed all the opportunities that microzonal agriculture, especially appellation wines have. We have discussed the theoretical and practical aspects of the Georgian winemaking and possibilities to develop Georgian viticulture with the help of Micro zones.

In the article we have analyzed how the development of the current wine microzones and establishment of new appellations can develop both social and economic situation of Georgian winemaking. How both of the cases affect the region.

The purpose of the development of micro regional winemaking is to increase the quality of wine production, also to create better quality control mechanisms and of course to make Georgian wine more popular on domestic and international markets. The development of micro zonal winemaking can be established with the help of international and local wine professionals and with the help of international experience.

In the end of the article we have summarized all the possibilities that we have discussed in the main part of the article and we have made recommendations for Georgian wine industry. All these possibilities can give us the possibilities to increase the economic profit and to develop the social situation of wine regions. 
Keywords: Wine Denomination of Origin, AOC, Microzonal Agriculture, VitiViniculture, Wine Economics.

\title{
13. The Importance of Business -Process Optimization for Modern Companies
}

\author{
Salome Imnaishvili \\ $\mathrm{PhD}$ Candidate, \\ Georgian Technical University \\ salome.imnaishvili777@gmail.com
}

\section{Resume}

Every business company is profit-oriented. The scale of profit is determined by the effectiveness of the activity, the quality of service provided to customers, speed of service, simplicity and all of the above -is the result of ongoing business-processes in the company. The forced stagnation can occur at any stage of the project development, however, even if it is not so, after a certain period, there always comes a moment, when changes in the work process are inevitable.

The prerequisite for the proper writing of business-processes is a thorough knowledge of the ongoing processes in the company and the existence of relevant qualified staff. Because if any link is dropped or misspelled during the business-process cycle, the whole business-process will be wrong and the result will inevitably affect the company's efficiency.

The Business-Process optimization has become vital for modern companies, especially in the age of digital technologies. The companies face the new challenges every day, and the modern technologies allow them to achieve their goals easily and at a much lower human or material costs.

Keywords: Business-Processes, Optimization, Qualified Staff, Company Efficiency. 


\title{
14. Emotional Intelligence and Spiritual Leadership: An Organizational Study
}

\author{
Rami Aljabali, \\ $\mathrm{PhD}$ Candidate at Caucasus School of Business \\ Rami_jabali@live.com
}

\begin{abstract}
Resume
The work addresses the problems in the field of organizational behavioral science and explores the emotional intelligence and spiritual leadership. The aim of this study is to understand the essence of emotional intelligence and spiritual leadership and their impact on organizational success, employee behavior, labor productivity, employees' jobs performance. The epistemological view of this study is subjective interpretivism and ontology, as the views, experiences, and behaviors of the participant in contextual social events are gathered to evaluate the results and draw conclusions. The research strategy is a case study, stratified sampling will be used for the data collection phase. The primary data are obtained from the qualitative data collection techniques such as the semi-structured interviews, observation and MSCEIT test.

Additionally, there is highlighted how the role of emotional stability, social skills and general mental capabilities play in employees' job performance as compared to IQ. This will emphasize the relationship between the emotional intelligence and job performance within different business sectors. Moreover, spiritual leadership is not something usually managers tend to utilize within their practice. This study will emphasize the importance of spiritual leadership mixed with high levels of emotional intelligence. Based on the findings, this research will suggest a new strategy for creating policies that will set employees on a path to reach their full potential in the organization.
\end{abstract}


Finally, the findings are supposed to shed a light on the effect of emotional intelligence and leadership's ability to increase overall productivity despite a person's IQ and academic capabilities.

Keywords: Organizational Behavior, Spiritual Leadership, Emotional Intelligence, IQ.

\title{
15. The Role of Benchmarking in Hotel Management Improvement
}

\author{
Nino Ositashvili, \\ $\mathrm{PhD}$ Student of GTU, \\ ninosit@yahoo.com ${ }^{1}$; \\ Nana Nadareishvili, \\ Doctor of Geography, Associate \\ Professor of GTU, Senior Research \\ Fellow at Vakhushti Institute of Geography \\ n.nadareish3005@gmail.com²
}

\section{Resume}

Hospitality is the most sensitive business in the world. Any small change in the country has an immediate impact on this industry. However, it should also be noted that this area also has the ability to recover quickly (coming out of various crises).

The world practice of successful hotel operation has shown that the presence of benchmarking companies in developed countries has brought good results to various enterprises. Since the hotel industry in Georgia is not yet developed to a level that meets international standards, it would be a good idea to create the regional hotel associations, to invite experts who provide benchmarking with their consulting activities and services. This means that the high-ranking experts will be invited to select the most important indicators for the analysis. Creating a service standard framework will help the hotel industry to improve the quality of a service.

Why is the knowledge of benchmarking tools important for hotels? Using benchmarking tools helps: 
1. Investors to determine a range of investment in the construction of a hotel based on the tariffs and occupancy in the market. What will the hotel room cost based on the investment and how long will it take to get the investment back?

2. Revenue management increase revenue; the best example of this is the benchmarking operations provided by the hotel chain Ritz Carton.

3. Hotels to have more satisfied customers. This means if the hotel rating is higher than that of other hotels, more customers are attracted.

4. To increase the qualification of hotel staff and to increase their motivation. This will improve the quality of the work done by them.

5. To save money on experiments; By using the best experience and offering your own option, the hotel will raise its awareness and increase its popularity.

Keywords: Benchmarking, Competition, Management, Hotel Services, Hospitality.

\title{
16. The Role of Liner Shipping Services in Small and Medium Sized
}

\section{Business Development}

\author{
Bagrat Devadze, \\ Academic Doctor of Economics, \\ Associate Professor of \\ Batumi Sea Maritime Academy \\ bagratdevadze267@gmail.com
}

\section{RESUME}

The Liner services provides regular shipments of goods between ports within the set timeframe. A fixed route, the obligation of receiving cargo and to go to sea with established schedule distinguishes line service from the sea transportation of bulk cargo.

Containerization, establishment and improvement of routes and infrastructure helped liner shipping to become the driving force of Global economy, which supports the growth 
of international trade, development of different business forms such as mainly small and medium sized businesses.

The shipment volume of containerized cargo was 37.1 M.TEU in 1994, by 2020 the figure reached up to $143.3 \mathrm{M}$.TEU. This indicator was growing at a high rate on East-West route during 1990-2016; In terms of North-South, South-South and intraregional route same measure was high between 1990-2004 years. Afterwards, Abovementioned growth has become more stable.

Containerization changed the structure of Liner fleet. If general cargo vessels deadweight was growing during 1970-2010 (From 40.5M Dwt to 99.7M Dwt), in the latest 10 years, the tonnage has been decreasing and as for 2020 it was 74.6M Dwt. In exchange for this the number of container ships have been growing consistently and in 2020 it consisted of 274.7M Dwt.

Maersk became the largest line operator since 2001 (with a market share of 9.4\%) and by 2020 it's share of the business has grown to 17\%. The company owns container terminals worldwide, including the Poti container terminal. MSC is on second place $(9.4 \%$ market share), COSCO is on third place (12.4\%) and CMA CGM takes forth place (11.8\%).

Keywords: Liner Shipping Services, Containerization, East-West routes, North-South routes, Intraregional routes, General cargo ship, Containership, Liner operator, Container port.

\section{Human resources - the Main Driving Force of the Organization}

Manana Samadashvili', PhD, GTU, Assistant Professor mako_sama20@yahoo.com ${ }^{1}$ Ekaterine Gobejishvili², Academic Doctor of GTU, Assistant Professor e.gobejishvili@gtu.ge ${ }^{2}$

\section{Resume}


In order to gain a competitive advantage in the business process, human resource management is a strategic approach to the organization or its staff. The importance of human resource management has undergone significant changes from administrative operations to more comprehensive functions.

Human resource functions exist and will exist in any type of organizations and companies as long as there is work in them. The transformation of new technologies for any professional field creates new needs and specialized functions for the use of human resources.

The methods used as a result of the introduction of new technologies in today's competitive environment allow to simplify work processes. It is interesting to use such new resources as: machine learning, big data and more. Digital technology requires changing work styles and procedures. Competitive professionals need to contribute to improving people's work experience.

Human resource management helps to achieve goals and objectives successfully. Only such a system maintains a motivated co-worker.

The development of artificial intelligence is far from perfect, there are many problems and only with the help of humans it is possible to overcome them. Thus it is necessary to hire modern staff and train them in terms of mastering and using digital technology. Technology is transforming our lives.

Key words: Human Resource Management, Digital HR, Artificial Intelligence, Benefits of Digital HR.

\section{DEVELOPMENT OF GEORGIA'S TRADE RELATIONS WITH UKRAINE}

\section{GRIGOL GLUNCHADZE,} Doctoral Student of Georgian Technical University, grigol.glunchadze@gmail.com 


\section{Resume}

The title of the article - "Development of Georgia's Trade Relations with Ukraine" shows Georgia's trade relations with Ukraine. According to the information presented in the article, which is spread over the years 2016-2020, in this 5-year period, the total trade turnover and export-import are increasing, which does not apply to the last 2020. This year, all the above indicators have been reduced - turnover by $9 \%$, exports - by $13 \%$, imports - by $6 \%$. The author connects this situation with the cooling of diplomatic relations between the two countries. Because of Saakashvili's personality and emphasizes that this situation has improved today.

Georgia has a special close economic and economic ties with Ukraine among the countries of the world. This applies not only to the export-import of goods, but also to tourist traffic, investment, employment, etc. Sh. This relationship was established in 1995 with the conclusion of the Free Trade Agreement [1].

One of the characteristic features of foreign trade between Ukraine and Georgia is the fact that Georgia's share in the total foreign trade of Ukrainian goods is insignificant (about 0.5\%), while Ukraine's share in Georgia's total trade turnover reaches $5.1 \%$. According to the results of January-September 2020, among all Georgia's trading partners, Ukraine ranks 7th in terms of trade turnover, 5th in terms of exports of goods and 8th in terms of imports of goods. Georgia-Ukraine turnover in 2020 compared to 2019 has decreased - by 9\%, exports - by $13 \%$, imports - by $6 \%$ (Table 1). Under these conditions, there is an increase in some goods, in particular, an increase in imports:

$>$ Beef - by $43 \%$;

Copton - by 17\%;

Milk and cream - by 29\%;

Flat rolled- by $10 \%$. 
As for exports from Georgia to Ukraine, the export of ferroalloys (17 times) and the export of scrap (6 times) have increased.

Key words: Ukraine, Georgia; Trade relations; Export-import. 


\section{Publication Requirements for Scientific Articles:}

The Journal, also articles are indexed in the international scientific base CROSSREF and are assigned an unique International Digital Object Identifier (DOI). (http://search.crossrf.org)

The articles to be published in the journal should include the new results of scientific research in the theoretical and other practical fields of economics, such as: Economic reform; Modern problems of economics; History of economic doctrines; Legal Provision of Market Economy; Finances, Banks, Exchange Markets; Regional Economy; Sectoral Economy; Current issues of Business, Marketing, Management;

World economy; Reviews on monographs and textbooks published recently.

All received scientific articles will be peer-reviewed by the Editorial Board and will be published in case of positive reviews and assessment. The accepted articles will be posted on the website, in the electronic journal.

The articles are published in Georgian, Russian, English, German and French languages, in the original language.

\section{Plagiarism and Ethical Requirements}

The Author is responsible for plagiarism and for the accuracy of the facts, data given in the article. It is not permissible to use others' text in the article without their cross-reference.

Moreover, it is also unacceptable to publish the early elsewhere issued article in the journal.

\section{The Requirements of Formatting scientific articles:}

The minimum volume of the article is 5 pages $\mathrm{A} 4$ format;

Resumes must be in Georgian and English (essential) languages (minimum 100-250 words);

Key words in Georgian and English languages;

Title of the article in Georgian and English languages; 
Name, surname, academic degree of the author (authors) in Georgian and English, E-mail and telephone number;

Introduction to the article, Basic text and Conclusion;

List of References in Georgian and English languages;

For Georgian text, please use the Georgian font AcadNusx.

For English and Russian texts please use Times New Roman;

Font size 12, the interval $1,5 \mathrm{~cm}$, Line Spacing- $2 \mathrm{~cm}$. 


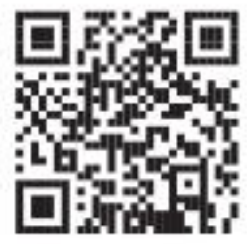

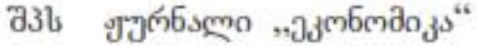

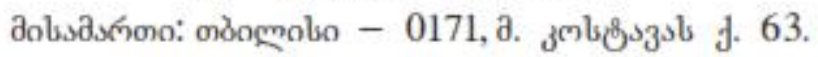 \\ ஓ̊วल: 599 56-90-78. \\ economics.bpengi.com \\ E-mail: economica_2008@yahoo.com \\ E-mail: economica_1918@yahoo.com
}

\title{
ООО журнал «ЭКОНОМИКА»
}

Адрес Тбилиси - 0171, ул. М. Костава 63

Тел. 599 56-90-78

economics.bpengi.com

E-mail: economica_2008@yahoo.com

E-mail: economica_1918@yahoo.com

\author{
L.

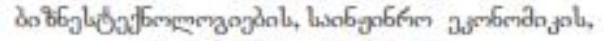

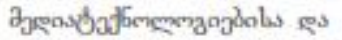

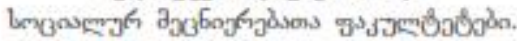

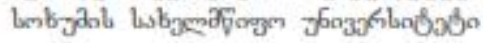

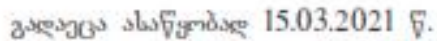 \\ by

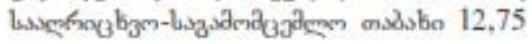


ๆ১З (UDC): 338(922)(05)

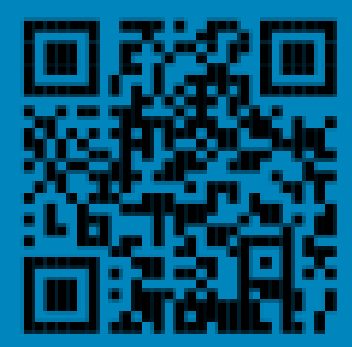

